\title{
EFEKTIVITAS DAN KONTRIBUSI PENERIMAAN PAJAK HOTEL TERHADAP PENDAPATAN ASLI DAERAH KOTA MAKASSAR TAHUN (2015-2019)
}

\author{
Risa Rukmana*1, Raodatul Jannah ${ }^{2}$, Nurlaila Hasmi ${ }^{3}$ \\ Jurusan Akuntansi Sekolah Tinggi Ilmu Ekonomi Tri Dharma Nusantara Makassar \\ e-mail: ${ }^{* 1}$ risarukmana@gmail.com,${ }^{2}$ raodatul.jannah@uin-alauddin.ac.id,${ }^{3}$ nurlailahasmi@yahoo.com
}

\begin{abstract}
Abstrak
Tujuan penelitian ini untuk mengetahui besarnya efektifitas dan kontribusi pajak hotel terhadap pendapatan asli daerah pada Kantor Dinas Pendapatan Asli Daerah Kota Makasar. Jenis data yang digunakan adalah data kuantitatif. Sumber data yang duigunakan adalah data sekunder. Metode pengumpulan data menggunakan metode dokumentasi terkait penelitian. Penelitian dianalisis dengan menggunakan metode analisis deskriptif kuantitafif. Hasil penelitian adalah tingkat efektifitas dan kontribusi pajak hotel tahun 2015-2019 dapat dikatakan"kurang efektif". Tingkat kontribusi penerimaan pajak hotel selama tahun 2015-2019 termasuk kategori "sangat berkontribusi" hal ini ditunjukkan oleh persentasi tingkat kontribusi sebesar 7,97\% sehingga mempengaruhi jumlah pendapatan asli daerah yang diterima.
\end{abstract}

Kata kunci: Efektivitas,Kontribusi, Pajak Hotel, Pendapatan Asli Daerah

\begin{abstract}
The purpose of this study was to determine the effectiveness and contribution of hotel taxes to local revenue at the Makassar City Original Revenue Service Office. The type of data used is quantitative data. The data source used is secondary data. The method of data collection uses the method of documentation related to research. The research was analyzed using quantitative descriptive analysis method. The results of the study are the level of effectiveness and contribution of hotel taxes in 2015-2019 can be said to be "less effective". The contribution rate of hotel tax revenue during 2015-2019 is included in the category of "highly contributing" this is indicated by the percentage of the contribution rate of $7.97 \%$ so that it affects the amount of local revenue received.
\end{abstract}

Keywords :_Effectiveness, Contribution, Hotel Tax, Local Revenue

\section{PENDAHULUAN}

Pemberian otonomi daerah yang seluas-luasnya tanpa ada pengecualian merupakan salah satu agenda reformasi yang dicita-citakan. Pemberian otonomi yang luas kepada daerah darahkan untuk mempercepat terwujudnya kesejahteraan masyarakat melalui peningkatan pelayanan, pemberdayaan sumber daya manusia, pemberdayaan suber-sumber keuangan, dan peran masyarakat daerah. Otonomi Daerah mempunyai kewenangan dan kebebasan untuk membentuk dan melaksanakan kebijakan menurut prakarsa dan aspirasi masyarakat. Kemajuan suatu daerah dapat terlaksana dengan baik jika pembangunan ekonomi juga berjalan dengan baik. Salah satu langkah yang dilakukan dengan cara mengelolah berbagai sumber daya untuk merangsang berjalan kegiatan ekonomi guna meningkatkan sumber penerimaan suatu daerah, tiaptiap daerah diberi kewenangan untuk mengelolah semaksmal mungkin sumber-sumber ekonomi dan keuangan yang dimiliki. Salah satu sumber penerimaan daerah berasal dari Pendapatan Asli Daerah. Pendapatan Asli Daerah adalah pendapatan yang diperoleh daerah yang dipungut berdasarkan peraturan daerah sesuai dengan peraturan perundangundangan. Penerimaan Asli Daerah adalah penerimaan dari pungutan pajak daerah, retribusi daerah, hasil dari perusahaan daerah dan lainnya yang merupakan sumber 
pendapatan asli daerah tersebut, yang digali atau dihasilkan oleh daerah yang bersangkutan dan merupakan pola pendapatan daerah yang sah. Pajak daerah, retribusi dan pendapatan daerah lainya merupakan sumber-sumber pemasukan daerah yang seharusnya dapat dikelolah dengan semaksimal mungkin untuk mengurangi ketergantungan suatu daerah terhadap pemerintah pusat. Pajak yang merupakan salah sumber penerimaan daerah adalah kontribusi wajib kepada daerah yang terutang oleh orang pribadi atau badan yang bersifat memaksa berdasarkan undang-undang, dengan tidak mendapatkan imbalan secara langsung dan digunakan untuk keperluan daerah bagi sebesar-besarnya kemakmuran rakyat. Pajak daerah memberikan konstribusi yang sangat besar untuk meningkatkan Pendapatan Asli Daerah. Adanya pajak daerah dapat digunakan untuk membiayai berbagai sumber-sumber pengeluaran suatu daerah.

Upaya yang dapat dilakukan untuk meningkatkan pendapatan asli daerah adalah dengan meningkatkan efesiensi sumber daya dan sarana dan meningkatkan efektifitas pemungutan sumber-sumber penerimaan daerah. Penerimaan pemerintah daerah berupa pajak daerah dapat dioptimalkan seoptimal mugkin hal ini disebabkan pajak mempunyai kontrbusi yang cukup tinggi dalam penerimaan negara dan berperan dalam pembangunan suatu negara. Pajak merupakan iuran wajin bagi masyarakat (wajib pajak), pajak yang diterima oleh daerah digunakan untuk membiayai pengeluaranpengeluaran pemerintah daerah seperti biaya administrasi, pendidikan, kesehatan, infrastruktur dan berbagai pengeluaran lain demi kemajuan suatu daerah. Pemungutan pajak diatur dalam Undang-Undang Nomor 28 Tahun 2009 tentang Pajak Daerah dan Retribusi Daerah. Pajak daerah dibagi mejadi dua jenis yakni; pajak provinsi (pajak kendaraan bermotor, pajak rokok, bea balik mana kendaran bermotor dan pajak air permukaan); pajak Kabupaten/ Kota (Pajak hotel, reklame, air tanah, sarang burung wallet, bumi dan bangunan dan bea perolehan ha katas tanah dan bangunan). Dinas Pendapatan Kota/Daerah adalah pihak yang berwenang atas pemungutan pajak.

Salah satu pajak daerah yang memliki potensi besar dalam meningkatkan pendapatan asli daerah adalah pajak hotel. Sektor parwisata merupakan salah satu sektor yang dari tahun ke tahun terus mengalami peningkatan hal ini dapat dilihat dari bertambahnya jumlah objek pariwisata di Kota Makassar Jumlah wajib hal ni berpengaruh terhadap pajak hotel terus meningkat seiring dengan berkembangnya sektor pariwisata di Kota Makassar. Peningkatan ini diharapkan dapat memberikan kontribusi terhadap penerimaan pajak daerah dan meningkatkan kesejahteraan masyarakat di Kota Makassar. Adapun penelitian terdahulu yang berkaitan dengan pajak daerah dan pendapatan daerah dilakukan oleh Fadillah (2017) dengan judul efektivitas dan kontribusi pajak hotel dan reklame terhadap peningkatan pendapatan asli daerah Kota Makassar dengan mengambil data tahun 2014- 2016. Metode analysis yag digunaka deskriptif kuantitatif. Hasil penelitiannya menunjukkan bahwa tingkat efektifitas penerimaan pajak hotel secara keseluruhan berdasarkan tahun analisis yakni tahun 2014-2016 tergolong "kurang efektif" karena tingkat persentase yang dicapai hanya 70,93\% dan hanya pada tahun 2014 yang realisasi melebihi target yang telah ditetapkan, sedangkan tahun 2015-2016 berturut-turut mengalamim penurunan. Sedangkan untuk pajak reklame tingkat efektifitas secara keseluruhan dari tahun 20142016 juga tergolong "kurang efektif" hal ini ditunjukkan oleh tingkat persentase yang dicapai hanya sebesar 77,42\% dan dar tahun 2014-2016 tingkat efektifitas untuk pajak reklame terus mengalami penurunan dilihat dari sudut pandang kontribusi pajak hotel terhadap Pendapatan Asli Daerah secara keseluruhan yakni dari tahun 2014-2016 
memberikan kontribusi baik sehingga mempengaruhi jumlah pendapatan asl daerah yang diterima sedangkan kotribusi untuk pajak reklame untuk tahun analisis yakni tahun 2014-2016 memberikan kontribusi yang tidak cukup bak bagi pendapatan asli daerah karena mengalami inflasi ditiap tahunnya. Penelitian ini bertujuan menggali kembali efektifitas dan kontribusi pajak hotel terhadap pendapatan asli daerah Kota Makassar dengan mengambil data terbaru yakni data lima tahun terakhir (2015-2019).

Candrasari dan Ngumar (2016) judul penelitian Kontribusi pajak hotel dan restoran terhadap peningkatan pendapatan asli daerah Kota Surabaya. Metode analisis yang digunakan deskriptif kualitatif, teknik pengumpulan data primer berupa hasil wawancara, observasi dan dokumentasi serta data sekunder berisi jumlah penerimaan pajak daerah. Hasil penelitian menujukkan potensi pajak tahun 2010-2014 mengalami peningkatan sesuai dengan peraturan pemerintah dalam pemungutan pajaknya. Tngkat efektifitas pajak hotel sangat efektif ditahun 2012-2014, peningkatan efektifitas tertinggi pada tahun 2012 sebesar 106,95\%. Efektifitas pajak restoran tahun 2012 sebesar 108,21\% menunjukkan peningkatan yang sangat efektif juga terjadi. Meskipun realisasi penerimaan pajak hotel dan restoran serta realisasi penerimaan pendapatan asli daerah meningkat tetapi kontribusi dari tahun 2010-2014 terus menurun dalam memberikan sumbangan peningkatan penerimaan daerah serta pemerintah juga tetap berupaya melakuka pembenahan dalam pemungutan pajaknya.

Wdodo \& Guritno (2017) judul penelitiannya adalah Pengaruh Pajak Hotel, Pajak Restoran dan Pajak Hiburan terhadap Pendapatan Asl Daerah (PAD) Di Kota Yogyakarta. Jenis penelitian ini adalah studi kasus dengan teknik pengumpulan data berupa wawancara dan dokumentasi. Teknik analisis data menggunakan regresi berganda hasil regresi menunjukkan bahwa ada penngaruh yang simultan dan signifikan antara pajak hotel, pajak restoran, dan pajak hiburan terhadap pendapatan asli daerah Kota Yogyakarta periode 2010-2014. Secara parsial pajak hotel, pajak restoran, da pajak hiburan berpengaruh pendapatan asli daerah dengan nilai signifikansi masingmasing 0,015, 0,014, dan 0,014.

Kobandaha \& Wokas (2016) judul penelitiannya adalah Analisis Kontribusi dan potensi pajak reklame dan pajak Hotel terhadap Pendapatan Asli Daerah Di Kota Kotamobagu. Metode analisis yang digunakan adalah metode analisis deskriptif. Data yang digunakan adalah data sekunder berupa data target dan realisasi penerimaan pendapatan asli daerah Kota Manado dari tahunn 2012-2015. Hasil penelitian menunjukkan bahwa penerimaan pajak reklame Kota Kotamobagu tahun anggaran 2012-2015 dinilai sangat efektif. Sedangkan pajak hotel patahu 2012-2014 dinilai efektif. Sedangkan tahun 2015 tidak efektif. Secarara keseluruhan kontribusi pajak reklame di Kota Kotamobagu tahun anggaran 2012-2015 hanya memberikan kontribusi pajak reklame rata-rata $1,75 \%$. Dalam 4 tahun terakhir. Sedangkan pajak hotel memeberikan kontribusi rata-rata sebesar $1,25 \%$ Walaupun kontribusi pajak reklame dan pajak hotel hanya kecil tai dapat mempengaruhi Pendapatan Asli Daerah Kota Kotamobagu. Potensi penerimaan Pajak Reklame dan Pajak Hotel dalatm tahun 2016 akan mengalami kenaikan.

Bahmin dan Wahyudi (2018) Judul penelitiannya adalah Pengaruh Pemungutan Pajak Hotel dan Pajak Hiburan terhadap Peningkatan Pendapatan Asli Daerah Kota Medan. Pendekatan penelitian yang digunakan adalah pendekatan asosiatif. Teknik pengumpulan data dengan teknik dokumentasi dan kepustakaan uji hipotesis menggunakan uji t. hasil penelitian menunjukkan bahwa pemungutan pajak hotel dan 
hiburan mengalami peningkatan tetapi masih ada yang tidak mencapai target. Berdasarkan uji hipotesis ditemukan hasil tidak ada pengaruh pajak hotel terhadap peningkatan pendapatan asli daerah ini ditunjukkanoleh nilai probabilitas sig yang lebih besar dari 0,05 yakni 0,666 . Uji hipotesi berikutnya untuk pengaruh pajak hiburan terhadap peningkatan pendapatan asli daerah ditemukan hasil bahwa ada pengaruh pajak hiburan terhadap peningkatan pendapatan asli daerah hali ini ditunjukkan oleh nilai probabilitas sig lebik kecil dari 0,05 yakni sebesar 0,038 .

\section{METODE PENELITIAN}

Penelitian ini dilakukan di Kantor Dinas Pendapatan Asli Daerah Kota Makassar yang beralamat di Jl. Urip Sumoharjo No. 8 Kota Makassar. Jenis data yang digunakan dalam penelitian ini adalah data kuantitatif yakni catatan yang berhubungan dengan laporan anggaran dan realisasi pendapatan asli daerah. Sumber data yang digunakan data sekunder. Metode pengumpulan data yang dilakukan adalah dokumetasi yakni mengumpulkan data-data dan informasi yang dibutuhkan dari dokumen-dokumen yang berkaitan dengan penelitian. Metode analisis yang digunakan dalam penelitian ini adalah metode analisis deskriptif kuantitatif. Analisis deskriptif kuantitatif dilakukan dengan cara mengumpulkan data-data, mengklasifikasi data, menginterpretasikan data dan menjabarkan data sehingga memberikan gambaran yang objektif. Penelitian ini mendeskripsikan realisasi dan potensi pajak hotel, menghitung efektivitas pemungutan pajak hotel dan menganalisis kontribusi pajak hotel terhadap pendapatan asli daerah.

\section{Analisis Efektivitas Pajak}

Efektivitas pajak hotel yang dimaksud adalah seberapa besar realisasi penerimaan pajak hotel berhasil mencapai target yang seharusnya dicapai pada suatu periode tertentu, dengan rumus:

$$
\text { Efektivitas }=\frac{\text { Realisasi Penerimaan Pajak Hotel }}{\text { Target Pajak Hotel }} \times 100 \%
$$

Tabel 1. Kriteria Efektivitas

\begin{tabular}{|c|c|c|}
\hline Prosentase & Kriteria & Kode \\
\hline$>100 \%$ & Sangat Efektif & SE \\
\hline$>90 \%-100 \%$ & Efektif & E \\
\hline$>80 \%-90 \%$ & Cukup Efektif & CE \\
\hline$>60 \%-80 \%$ & Kurang Efektif & KE \\
\hline$<60 \%$ & Tidak Efektif & TE \\
\hline
\end{tabular}

\section{Analisis Kontribusi}

Analisis Kontribusi adalah alat analisis yang digunakan untuk mengetahui seberapa besar kontribusi yang dapat disumbangkan dari penerimaan pajak hotel terhadap pendapatan asli daerah. Rumus yang digunakan:

$$
P n=\frac{Q X n}{Q Y n} \times 100 \%
$$

Keterangan:

Pn = Kontribusi penerimaan pajak hotel terhadap PAD 


$$
\begin{array}{ll}
\text { QXn } & =\text { Jumlah Penerimaan Pajak Hotel } \\
\text { QYn } & =\text { Jumlah Penerimaan PAD } \\
\mathrm{N} & =\text { Tahun }
\end{array}
$$

Tabel 2 Klasifikasi Kriteria Kontribusi

\begin{tabular}{|c|c|c|}
\hline Prosentase & Kriteria & Kode \\
\hline$>4 \%$ & Sangat mempunyai kontribusi & SB \\
\hline $3 \%-3,9 \%$ & Mempunyai kontribusi & B \\
\hline $2 \%-2,9 \%$ & Cukup Mempunyai kontribusi & CB \\
\hline $1 \%-1,9 \%$ & Kurang Mempunyai kontribusi & KB \\
\hline $0 \%-0,9 \%$ & Tidak Mempunyai kontribusi & TB \\
\hline
\end{tabular}

\section{HASIL DAN PEMBAHASAN}

\section{Pertumbuhan Realisasi Pajak Hotel Tahun 2015-2019}

Pertumbuhan pajak hotel dianalisis dengan melihat perubahan realisasi pajak hotel tahun ke-n dengan tahun sebelumny (n-1). Tingkat pertumbuhan pajak hotel dinyatakan dalam persentase, seperti yang ditunjukkan pada tabel 1 berikut:

Tabel 3. Pertumbuhan Realisasi Pajak Hotel Tahun 2015-2019

\begin{tabular}{|c|c|c|}
\hline Tahun Anggaran & $\begin{array}{l}\text { Realisasi Pajak Hotel } \\
\text { (Rp) }\end{array}$ & Pertumbuhan (\%) \\
\hline 2014 & 50.533 .548 .736 & - \\
\hline 2015 & 50.128 .251 .233 & $-0,80$ \\
\hline 2016 & 70.091 .035 .799 & 39,82 \\
\hline 2017 & 92.970 .091 .185 & 32,64 \\
\hline 2018 & 103.142 .302 .558 & 10,94 \\
\hline 2019 & 120.484 .485 .188 & 16,81 \\
\hline
\end{tabular}

Sumber: Data diolah (2021)

Pertumbuhan realisasi pajak hotel mengalami peningkatan dari tahun ke tahun, selama rentang 5 tahun terakhir yakni dari Tahun 2015 sampai dengan Tahun 2019. Total penerimaan pajak hotel pada Tahun 2015 adalah Rp 50.128.251.233 merupakan penerimaan pajak hotel terendah, selanjutnya tahun 2016 naik sebesar 39,82\%. Pertumbuhan ini adalah pertumbuhan dengan persentase terbesar yakni penerimaan pajak hotel di Tahun 2016 sebesar Rp 70.091.035.799 peningkatan ini dikarenakan jumlah hotel sebagai wajib pajak juga bertambah terhitung jumlah hotel yang terdaftar pada Tahun 2015 adalah 302 dan naik menjadi 369 hal ini menunjukkan kenaikan sebanyak 67 wajib pajak hotel di Tahun 2016 atau mengalami petumbuhan sebesar 22,19\%. Tahun 2016 ke Tahun 2017 pertumbuhan mengalami penurunan sebesar $32,64 \%$ Hal yang sama juga terjadi di Tahun 2018 pertumbuhan mengalami penurunan sebesar 10,94\% dan kembali naik di tahun 2019 sebesar 16,81\%.

\section{Analisis Efektivitas}

Tabel 4. Perhitungan Efektivitas Pajak Hotel Tahun 2015-2019

\begin{tabular}{|c|c|c|c|c|}
\hline Tahun & $\begin{array}{c}\text { Target } \\
(\mathbf{R p})\end{array}$ & $\begin{array}{c}\text { Realisasi Pajak } \\
\text { Hotel } \\
(\mathbf{R p})\end{array}$ & $\begin{array}{c}\text { Efektivita } \\
\mathbf{S} \\
(\boldsymbol{\%})\end{array}$ & Keterangan \\
\hline 2015 & 81.208 .967 .000 & 50.128 .251 .233 & 61,72 & Kurang Efektif \\
\hline
\end{tabular}




\begin{tabular}{|c|c|c|c|c|}
\hline Tahun & $\begin{array}{c}\text { Target } \\
\text { (Rp) }\end{array}$ & $\begin{array}{c}\text { Realisasi Pajak } \\
\text { Hotel } \\
\text { (Rp) }\end{array}$ & $\begin{array}{c}\text { Efektivita } \\
\text { s } \\
(\%)\end{array}$ & Keterangan \\
\hline 2016 & 138.182 .620 .000 & 70.091.035.799 & 50,72 & Tidak Efektif \\
\hline 2017 & 120.000 .000 .000 & 92.970 .091 .185 & 77,47 & Kurang Efektif \\
\hline 2018 & 130.000 .000 .000 & 103.142 .302 .558 & 79,34 & Kurang Efektif \\
\hline 2019 & 135.000 .000 .000 & 120.484 .485 .188 & 89,24 & Cukup Efektif \\
\hline \multicolumn{3}{|c|}{ Rata-rata } & 71,70 & Kurang Efektif \\
\hline
\end{tabular}

Sumber: Data diolah (2021)

Dari tabel di atas dapat dilihat bahwa realisasi penerimaan pajak hotel tahun 2015 sebesar 61,72\% termasuk "kurang efekti", tahun 2016 sebesar 50, $72 \%$ termasuk "tidak efektif", realisasi penerimaan pajak hotel pada tahun 2016 ini adalah realisasi penerimaan pajak yang tingkat efektifitasnya paling rendah selama kurung waktu 5 tahun dari data yang dianalisis. Adapun persentasi penurunan tingkat efektifitas dari tahun 2015-2016 adalah sebesar 11\%. Pada tahun 2017 efektifitas realisasi penerimaan pajak hotel termasuk kategori "kurang efektif" yakni persentase sebesar 77,47\% walaupun masih termasuk kategori kurang efektif tetapi realisasi penerimaan pajak di tahun 2016 ini mengalami kenaikan disbanding tahun 2016, yakni kenaikan persentase efektifitasnya sebesar 26,75\%. Persentase kenaikan tingkat efektifitas di tahun 2017 ini adalah persentase kenaikan paling tinggi dari tahun ke tahun selama kurung waktu 5 tahun dari data yang dianalsis. Tahun 2018 tingkat efektifitas masih termasuk kategori "kurang efektif" yakni persentase efektifitas sebesar 79,34\%. Persentase efektifitas dari tahun 2017 ke tahun 2018 masih mengalami kenaikan walaupun relative kecil yakni sebesar 1,87\%. Tahun 2019 adalah tahun dengan tingkat efektifitas terbesar yakni sebesar 89,24 \% dan termasuk kategori tingkat efektifitas “cukup efektif'. Di tahun 2019 realisasi penerimaan pajak dari tahun 2018 mengalami kenaikan sebesar 9,9\%. Rata-rata tingkat efektifitas penerimaan pajak selama 5 tahun sebesar $71,70 \%$ dan termasuk kategori tingkat efektifitas "Kurang Efektif".

\section{Analisis Kontribusi}

Tabel 5. Kontribusi Pajak Hotel Tahun 2015-2019

\begin{tabular}{|c|c|c|c|c|}
\hline Tahun & $\begin{array}{c}\text { Penerimaan PAD } \\
(\mathbf{R p})\end{array}$ & $\begin{array}{c}\text { Penerimaan } \\
\text { Pajak Hotel } \\
\text { (Rp) } \\
\end{array}$ & $\begin{array}{c}\text { Tingkat } \\
\text { Kontribusi } \\
(\%) \\
\end{array}$ & Keterangan \\
\hline 2015 & 828.871 .892 .851 & 50.128 .251 .233 & 6,04 & Sangat Berkontribusi \\
\hline 2016 & 971.859 .753 .605 & 70.091 .035 .799 & 7,21 & Sangat Berkontribusi \\
\hline 2017 & 1.337 .231 .094 .232 & 92.970 .091 .185 & 6,95 & Sangat Berkontribusi \\
\hline 2018 & 1.281.431.350.183 & 103.142 .302 .558 & 8,04 & Sangat Berkontribusi \\
\hline 2019 & 1.073 .061 .660 .653 & 120.484 .485 .188 & 11,62 & Sangat Berkontribusi \\
\hline & \multicolumn{2}{|l|}{ Rata-rata } & 7,97 & Sangat Berkontribusi \\
\hline
\end{tabular}

Sumber: Data diolah (2021)

Dari tabel 5 di atas dapat dilihat bahwa persentase tingkat kontribusi tahun 2015 sebesar 6,04\% termasuk kategori "sangat berkontribusi". Persentase Tingkat kontribusi penerimaan pajak hotel dari tahun 2015 ke tahun 2016 mengalami kenaikan sebesar 
$1,17 \%$ dan merupakan persentase tingkat kontribusi terendah selama kurung waktu 5 tahun dari data yang dianalisis. Tahun 2016 persentase tingkat kontribusi sebesar 7,21\% persentase tingkat kontribusi penerimaan pajak tahun 2016 termasuk kategori "sangat berkontribusi". persentase tingkat kontribusi penerimaan pajak hotel yang terjadi di tahun 2017 megalami penuruanan sebesar 0,26\% penurunan persentase tingkat kontribusi ini tidak signifikan. Di tahun 2018 persentase tingkat kontribusi penerimaan pajak hotel kembali mengalamit kenaiakan yakni sebesar 8,04\% persentase kenaikannya mencapai $1,09 \%$. Persentase kenaikan tingkat kontribusi terbesar terjadi pada tahun 2019 kenaikanya mencapai 3,58\%. Persentase kenaikan yang terjadi di tahun 2019 adalah persentase kenaikan paling tinggi selama kurung waktu 5 tahun dari data yang dianalisis dan sekaligus termasuk persentase tingkat sebesar terjadi di tahun 2019 denngan persentasi kontribusi $11,62 \%$ dan tingkat kontribusi tertinggi yakni sebesar $11,62 \%$ termasuk kategori tingkat kontribusi "sangat berkontribusi" adapun rata-rata persentase tingkat kontribusi selama tahun 2015 sampai dengan tahun 2019 sebesar 7,97\% dan termasuk kategori "sangat berkontribusi" terhadap penerimaan pendapatan asli daerah (PAD) Kota Makassar.

\section{PEMBAHASAN}

Pajak adalah iuran rakyat kepada kas negara berdasarkan undang-undang (yang dapat dipaksakan) dengan tidak mendapat jasa timbal (kotraprertasi) yang langsung dapat ditunjukkan dan digunakan untuk membayar pengeluaran umum lebih lanjut (Mardiasmo ,2019). Pergertian lain juga dikemukakan oleh Resmi (2019) pajak adalah peralihan kekayaan dari pihak rakyat kepada kas negara untuk membiayai pengeluaran rutin dan surplusnya digunakan untuk public saving yang merupakan sumber utama untuk membiayai public investment. Salah satu fungsi dari pajak adalah fungsi penerimaan yakni sebagai sumber dana yang diperuntukkan bagi pembiayaan pengeluaran-pengeluaran pemerintah. (Waluyo, 2017) pengeluaran dapat berupa biaya administrasi, biaya pendidikan, biaya kesehatan, infrastruktur dan berbagai pengeluaran lain yang diperuntukan untuk kemajuan dan kesejahteraan suatu daerah. Pajak daerah merupakan pajak yang ditetapkan oleh pemerintah daerah dengan peraturan daerah (Perda), yang wewenang pemungutannya dilaksanakan oleh pemerintah daerah dan hasilnya digunakan untuk membiayai pengeluaran pemerintah daerah dalam melaksanakan penyelenggaraan pemerintahan daerah dan pembangunan daerah. Salah satu pajak yang dipungut oleh daerah adalah pajak hotel (Siahaan, 2016). Pajak Hotel adalah pajak atas pelayanan yang disediakan oleh hotel. Pajak hotel termasuk jenis pajak kabupaten/kota dimana tarif pajak yang dikenakan untuk pajak hotel adalah 10\% (sepuluh persen). Menurut Undang-Undang Nomor 33 Tahun 2004 tentang Perimbangan Keuangan antara Pemerntah Pusat dan Daerah, Pendapatan Asli Daerah (PAD) adalah pendapatan yang diperoleh daerah yang dipungut berdasarkan Peraturan Daerah yang bersumber dari hasil pajak daerah, hasil retribusi daerah, hasil pengelolaan daerah yang dipisahkan dan lain-lain pendapatan asli daerah yang sah. Pendapatan asli daerah dikategorikan sebagai pendapatan rutin dalam Anggaran Pendapatan dan Belanja Daerah (APBD). Pendapatan asli daerah merupakan suatu pendapatan yang menunjukkan suatu suatu kemampuan daerah menghimu sumbersumber dana untuk membiayai kegiatan rutin maupun pembangunan Semakin efektif pajak yang dipungut maka semakin baik pula pertumbuhan pajaknya sehingga dapat meningkatkan Pendapatan Asli Daerah (PAD). 
Salah satu pajak daerah yang potensinya semakin berkembangan seiring dengan semakin diperhatikannya komponen sektor jasa dan pariwisata dalam kebijakan pembangunan sehingga dapat menunjang perkembangannya bisnis rekreasi (pariwisata) adalah pajak hotel (Rualiaty dkk, 2018). Tingkat efektifitas penerimaan pajak hotel dapat diukur dengan melihat perbandingan antara realisasi penerimaan pajak hotel dan target pajak hotel yang akan dicapai dalam suatu periode. Berdasarkan hasil analisis perhitungan efektifitas penerimaan pajak hotel selama 5 tahun yang dilakukan di Kota Makassar, adapun yang termasuk kategori kurang efektif terjadi pada tahun 2015, 2017 dan 2018 hal menunjukkan bahwa realisasi penerimaan pajak hotel belum memenuhi target yang diinginkan. Bahkan di tahun 2016 realisasi penerimaan pajak hotel termasuk tidak efektif hal ini ditunjukkan dari persentasi tingkat efektivitas hanya mencapai $50,72 \%$ hal ini berarti bahwa hanya 50,72\% dari target yang diinginkan dapat terealisasi. Realisasi penerimaan pajak hotel pada tahun 2016 ini adalah realisasi penerimaan pajak yang tingkat efektifitasnya paling rendah. Tahun 2019 realisasi penerimaan pajak hotel terbesar yakni mencapai $89,24 \%$ hal ini berarti bahwa sebesar $89,24 \%$ penerimaan pajak hotel yang terealisasi dari target yang diinginkan dan termasuk kategori cukup efektif. Secara keseluruhan dari data yang dianalisis rata-rata tingkat efektifitas penerimaan pajak selama 5 tahun sebesar $71,70 \%$ dan termasuk kategori tingkat efektifitas "Kurang Efektif". Dilihat dari hasil analisis tingkat efektifitas yang termasuk kategori kurang efektif menunjukkan kinerja Dinas Pendapatan Daerah Kota Makassar belum mencapai target yang diinginkan hal juga menunjukkan bahwa jumlah penerimaan pajak hotel yang berhasil diwujudkan atau dipungut selama kurun waktu lima tahun adalah 71,70\% dari target yang ditentukan.

Kontribusi pajak hotel terhadap Pendapatan Asli Daerah (PAD) dapat dihitung dengan melhat perbandingan antara realisasi penerimaan pajak hotel dengan realisasi penerimaan pendapatan asli daerah. Berdasarkan hasil analisis dapat dilihat dari kontribusi penerimaan pajak hotel selama tahun 2015-2019 secara keseluruhan termasuk kategori sangat berkontribusi hal ini ditunjukkan dari rata-rata tingkat kontribusi selama 5 tahun sebesar 7,97\% hal ini berarti pajak hotel sangat berkontribusi terhadap pendapatan asli daerah Kota Makassar. Tingkat kontribusi penerimaan pajak hotel dari tahun 2015 ke tahun 2016 mengalami peningkatan dan turun kembali pada tahun 2017, tetapi tahun 2018 sampai dengan tahun 2019 kembali mengalami kenaikan dan tahun 2019 adalah persentase kenaikan paling tinggi selama kurung waktu 5 tahun dari data yang dianalisis dan sekaligus termasuk persentase paling tinggi dengan persentasi kontribusi 11,62\%. Hasil ini menunjukkan bahwa secara keseluruhan pajak hotel sangat berkontribusi dalam menngkatkan Pendapatan Asli Daerah (PAD) Kota Makassar pada tahun yang dianalisis yakni (2015-2019). Hasil penelitian ini sejalan dengan penelitian yang dilakukan oleh Fadillah (2017).

\section{KESIMPULAN}

Berdasarkan penjelasan dari hasil penelitian mengenai tingkat efektifitas dan kontribusi pajak hotel tahun 2015-2019.

1. Tingkat efektifitas penerimaan pajak hotel selama tahun 2015 sampai dengan tahun 2019 termasuk kategori kategori "kurang efektif" hal ini ditunjukkan oleh persentasi tingkat efektifitas sebesar 70,71\%. Angka ini menunjukkan bahwa 


\section{AkMen \\ Volume 18 Nomor 2 Agustus 2021 \\ Hal. 188 - 197 \\ e-ISSN : 2621-4377 \& p-ISSN : 1829-8524 \\ Hbmepage: https//e-jurnal.nobel.acid/index.php/akmen}

kinerja Dinas Pendapatan Kota Makassar belum mencapai target yang diinginkan.

2. Tingkat kontribusi penerimaan pajak hotel selama tahun 2015 sampai dengan tahun 2019 termasuk kategori "sangat berkontribusi" hal ini ditunjukkan oleh persentasi tingkat kontribusi sebesar 7,97\%. Angka ini menunjukkan bahwa pajak hotel sangat berkontribusi terhadap pendapatan asli daerah Kota Makassar.

\section{SARAN}

Penelitian ini memiliki keterbatasan berkaitan dengan belum diperolehnya data terbaru berkaitan dengan penerimaan pajak hotel yang terjadi tahun 2020, mengingat diawal tahun 2020 adalah awal terjadinya pademi COVID-19 yang berdampak pada berbagai sektor, sehingga penulis menyarankan untuk penelitian selanjutnya memasukkan data-data terbaru berkatan dengan penerimaan pajak hotel pada Dinas Pendapatan Kota Makassar. penulis menyarankan kepada Dinas Pendapatan Daerah Kota Makassar agar lebih meningkatkan efektifitas dengan melakukan pendataan wajib pajak hotel yang ada di Kota Makassar dan juga berupaya meningkatkan penagihan terhadap wajib pajak yang melakukan penunggakan karena hal ini akan bepengaruh terhadap tingkat efektifitas yang dihasilkan.

\section{DAFTAR PUSTAKA}

Candrasi. A \& Ngumar S. 2016. Kontribusi pajak hotel dan restoran terhadap peningkatan pendapatan asli daerah Kota Surabaya. Jurnal Ilmu dan Riset Akuntansi : Volume 5, Nomor 2, Februari 2016. ISSN : 24600585

Fadillah, Nur. 2017. Efektivitas dan Kontribusi Pajak Hotel Dan Reklame Terhadap Peningkatan Pendapatan Asli Daerah Kota Makassar. Skripsi. Universitas Muhammadiyah Makassar.

Kobandaha R. \& Analisis Kontribusi dan potensi pajak reklame dan pajak Hotel terhadap Pendapatan Asli Daerah Di Kota Kotamobagu. Jurnal EMBA Vol.4 No.1 Maret 2016, Hal. 1461-1472

Mardiasmo. 2019. Perpajakan. Edisi Revisi. Penerbit Andi. Yogyakarta.

Resmi, Siti. 2019. Perpajakan : Teori dan Kasus. Jakarta : Salemba Empat.

Rualiaty, Arman, Kasmida. 2018. Efektivitas Penerimaan Pajak Hotel Dan Kontribusinya Terhadap Peningkatan Pendapatan Asli Daerah (Pad) Kota Makassar. Amnesty: Jurnal Riset PerpajakanVol 1, Nomor 2.

Siahaan, Marihot. 2016, Pajak Daerah dan Retribusi Daerah. Edisi Revisi. PT. Raja Grafindo Persada. Jakarta.

Undang-Undang Nomor 28 Tahun 2009 Tentang Pajak Daerah dan Retribusi Daerah. 
Undang-Undang Nomor 33 Tahun 2004 Tentang Perimbangan Keuangan antara Pemerintah Pusat dan Daerah, Pendapatan Asli Daerah (PAD)

Waluyo. 2017. Perpajakan Indonesia. Edisi 12. Jakarta: Salemba Empat.

Widodo W.I \& Guritno B.2017. Pengaruh Pajak Hotel, Pajak Restoran dan Pajak Hiburan terhadap Pendapatan Asl Daerah (PAD) Di Kota Yogyakarta. Jurnal Visi Manajemen Vol 2 No 2. 